\title{
New Approach for Lead, Zinc and Copper Ions Elimination in Cyanidation Process to Improve the Quality of the Precipitate
}

\author{
José R. Parga' ${ }^{1}$, Jesús V. Valdés ${ }^{1}$, Jesús L. Valenzuela² ${ }^{2}$ Gregorio Gonzalez ${ }^{3}$, \\ L. María de J. Pérez ${ }^{1}$, T. Francisco Cepeda ${ }^{1}$ \\ ${ }^{1}$ Department of Materials Science and Metallurgy, Technological Institute of Saltillo, Saltillo, México \\ ${ }^{2}$ Departament of Chemical Engineering and Metallurgy, University of Sonora, Hermosillo, México \\ ${ }^{3}$ Faculty of Metallurgy, University of Coahuila, Monclova, México \\ Email: gregorio55@gmail.com
}

Received 6 January 2015; accepted 25 January 2015; published 30 January 2015

Copyright (C) 2015 by authors and Scientific Research Publishing Inc.

This work is licensed under the Creative Commons Attribution International License (CC BY).

http://creativecommons.org/licenses/by/4.0/

(c) (i) Open Access

\begin{abstract}
The Merrill-Crowe zinc-precipitation process has been applied worldwide on a large number of operations for recovering gold and silver from cyanide solutions. However, in some of the large plants this precipitate is of low quality, because copper and especially lead are precipitated along with gold and silver resulting in a higher consumption of zinc powder, fluxes in the smelting of the precipitate, formation of mate and short life for crucibles. In this research, a method is proposed to recover lead, zinc and copper cyanide ions from barren solutions, from the Merrill-Crowe process with hydroxyapatite before the filter press. This technology is based on inducing nucleated precipitation of zinc, copper and silver ions in a serpentine reactor, using sodium sulfide as the precipitator and sulfuric acid for $\mathrm{pH}$ control. This procedure was successfully applied at WILLIAM Mining and BACIS Mining Group in México.
\end{abstract}

\section{Keywords}

Gold-Silver Recovery, Hydroxyapatite, Merrill-Crowe, Sulphide Precipitation

\section{Introduction}

Cyanidation of gold and silver ores is a complex heterogeneous process, where the leaching behavior of gold depends upon the nature of the gold and silver bearer as well of its distribution within the ore with respect to its

*Corresponding author.

How to cite this paper: Parga, J.R., Valdés, J.V., Valenzuela, J.L., Gonzalez, G., Pérez, L.M.J. and Cepeda, T.F. (2015) New Approach for Lead, Zinc and Copper Ions Elimination in Cyanidation Process to Improve the Quality of the Precipitate. Materials Sciences and Applications, 6, 117-129. http://dx.doi.org/10.4236/msa.2015.62015 
ability to be reached by the liquid phase. It also depends on the quality of the gold surface exposed to cyanide. The gold was recovered by gravity separation or by amalgamation with mercury (harmful practice). Cyanidation, a chemical process for gold dissolution, was introduced about 1890 in New Zealand and South Africa. It replaced the chlorination method, which had been in use [1] [2].

The cyanidation process involved two steps:

1) dissolution of gold from ores by an alkali cyanide solution;

2) recovery or cementation of gold from the leach solution by metallic zinc powder.

In 1900, the flotation process was first used for concentrate fine hydrophobic particles of gold to rising bubbles in a flotation cell and this froth process came into general use in the 1930's. Then heap leaching, essentially a form of cyanidation treatment, came into general practice for the treatment of low-grade ores in 1970. Later, the hydrometallurgy of gold greatly advanced in 1973 with the widespread application of activated carbon technology and aqueous oxidation of gold refractory ores [3]. It is widely accepted that gold dissolution in cyanide solutions occurs as sequence of two reactions shown in Equations (1) and (2). These reactions apply to silver as well.

$$
\begin{aligned}
2 \mathrm{Au}+4 \mathrm{NaCN}+\mathrm{O}_{2}+2 \mathrm{H}_{2} \mathrm{O} & \rightarrow 2 \mathrm{Na}\left[\mathrm{Au}(\mathrm{CN})_{2}\right]+2 \mathrm{NaOH}+\mathrm{H}_{2} \mathrm{O}_{2} \\
2 \mathrm{Au}+4 \mathrm{NaCN}+\mathrm{H}_{2} \mathrm{O}_{2} & \rightarrow 2 \mathrm{Na}\left[\mathrm{Au}(\mathrm{CN})_{2}\right]+2 \mathrm{NaOH}
\end{aligned}
$$

Elsner's Equation (1) shows that oxygen is critical for the dissolution of gold. The stoichiometry of the process shows that 4 moles of cyanide are needed for each mole of oxygen present in solution. At room temperature and standard atmospheric pressure, approximately $8.2 \mathrm{mg}$ of oxygen are present in one liter of water. This corresponds to $0.27 \times 10^{-3} \mathrm{~mol} \cdot \mathrm{L}^{-1}$. Accordingly, the sodium cyanide concentration (molecular weight of NaCN $=49$ ) should be equal to $4 \times 0.27 \times 10^{-3} \times 49=0.05 \mathrm{~g} \cdot \mathrm{L}^{-1}$ or approximately $0.01 \%$. This was confirmed in practice at room temperature by a very dilute solution of $\mathrm{NaCN}$ of $0.1 \%-0.5 \%$ for ores, and for concentrates rich in gold and silver of $0.5 \%-5 \%$ [3]. Also, lime is added to keep the system at an alkaline $\mathrm{pH}$ of 10.5 - 11.0. This protective alkalinity is required to counteract the generation of acid during cyanidation, thereby preventing cyanide degradation and the formation of deadly HCN gas.

Other factors affecting gold leaching kinetics are grain size, agitation speed, temperature, pressure, foreign ions, cyanicides and carbon preg-robbing [4] [5]. In the cyanidation process, it is always necessary to bleed some of the leach solution to maintain a tolerable level of impurities ions like copper and lead since the bulk of the cyanide solution is recycled. The bleed solution, however, is poisonous and must be destroyed before disposal in the environment. Thus, the cyanide present in either form has a high degree of toxicity that needs treatment. In normal conditions, cyanide can be reduced by natural degradation mechanisms, by means of exposure of the cyanide solution to solar radiation in large settling ponds or cyanide removal by volatilization of free cyanide. Since the natural degradation process needs proper climatic conditions to be efficient, the use of a procedure involving chemical oxidation to accelerate the destruction of cyanide is often mandatory [6].

In cyanidation plants, the concentration of cyanide used to dissolve gold in ores is typically higher than the stoichiometric ratio, due to the solubility of other minerals [7]. Free cyanide produces complexes with several metallic species, especially transition metals, which show a broad variation in both stability and solubility. Many common copper minerals are soluble in the dilute cyanide solution, typical of leach conditions found in the gold cyanidation process. Minerals such as azurite and malaquite, are fast leached and soluble in dilute cyanide solutions [8]. Enargite and chalcopyrite leach more slowly but are sufficiently soluble to cause excessive cyanide loss and contamination of leach solutions with arsenic. Also, lead ores like galena and anglesite behave similarly toward cyanide, as the reactive effect of galena is largely due to the ease with which it oxidizes to sulphate. It is important to use low concentrations of alkali; otherwise excessive amounts of alkaline plumbite will be formed, which will interact with the cyanide present to form basic insoluble lead cyanide; the main reactions are probably Equations (3) and (4):

$$
\begin{gathered}
4 \mathrm{NaOH}+\mathrm{PbSO}_{4} \rightarrow \mathrm{Na}_{2} \mathrm{PbO}_{2}+\mathrm{Na}_{2} \mathrm{SO}_{4}+2 \mathrm{H}_{2} \mathrm{O} \\
3 \mathrm{Na}_{2} \mathrm{PbO}_{2}+2 \mathrm{NaCN}+4 \mathrm{H}_{2} \mathrm{O} \rightarrow \mathrm{Pb}(\mathrm{CN})_{2} \cdot 2 \mathrm{PbO}+8 \mathrm{NaOH}
\end{gathered}
$$

With low concentrations of alkaline, plumbite, a less basic lead cyanide, is formed. Therefore, hydrometallurgical treatment of these ores by cyaniding as a rule gives rise to a series of difficulties associated with increase 
in the cyanide and oxygen consumption rates and decrease in the dissolution rate of gold and silver, and in the cementation process, this precipitate is of low quality, because the copper and especially lead are precipitated along with gold and silver, resulting in a higher consumption of zinc dust [9], fluxes in the smelting of the precipitate and shorter life for crucibles. In this regard, a study is proposed to remove lead ions with hydroxyapatite and copper cyanide ions from barren solutions from the Merrill-Crowe process. This technology is based on inducing nucleated precipitation of copper and silver in a serpentine reactor, using sodium sulfide as the precipitator, and sulfuric acid for $\mathrm{pH}$ control.

Sulphide precipitation of metals is a viable alternative process for copper recovery from the barren cyanide solutions because of the possible high grade of metal removal over a broad $\mathrm{pH}$ range [1]. For the application of copper and cyanide recovery after cyanidation, the key advantage of a sulphide precipitation process is the ability to operate in the barren solution to recover first the copper/silver and then the acidic conditions in the solution result in rapid release of free cyanide $\left(\mathrm{HCN}_{\mathrm{gas}}\right)$ that is easily recoverable by volatilization at lowered $\mathrm{pH}$ value [6] [10]. If the cyanide is present in the barren solution after precipitation from the Merrill-Crowe process as free cyanide ( $\mathrm{pKa}=9.4$ ), it is possible to convert $99 \%$ of the cyanide into HCN gas (Equation (5)) by lowering the $\mathrm{pH}$ of the solution to about 6 :

$$
\mathrm{CN}^{-}+\mathrm{H}^{-} \rightarrow \mathrm{HCN}_{(\text {gas })}
$$

From this chemical equation, we can see that the concentration of free cyanide is the sum of the $\mathrm{CN}^{-}$and HCN concentrations, and the distribution is illustrated by the equilibrium diagram shown in Figure 1. This figure shows the proportions of free cyanide as $\mathrm{CN}^{-}$and $\mathrm{HCN}$ as a function of $\mathrm{pH}$ at $25^{\circ} \mathrm{C}$. At $\mathrm{pH}$ values above $\mathrm{pH}$ 9.2, $\mathrm{CN}^{-}$predominates, and at $\mathrm{pH}$ values below 9.2, $\mathrm{HCN}$ predominates.

In addition to free cyanide, other complexes such as the metal cyanide complexes formed with gold, mercury, zinc, cadmium, silver, copper, nickel, iron and cobalt must be considered. These are classified into five general categories, as shown in Table 1 [11].

If, on the other hand, the cyanide is present as a metal-cyanide complex, the $\mathrm{pH}$ must be reduced to more acidic values to break down the complex and produce HCN gas. For example, the weak zinc-cyanide complex $\left(\log B_{4}=17.4\right)$ breaks down completely at about $\mathrm{pH} 5$, producing zinc sulfate as an aqueous soluble species, plus 4 moles of HCN gas in Equation (6):

$$
\mathrm{Zn}(\mathrm{CN})_{4}^{2-}+2 \mathrm{H}_{2} \mathrm{SO}_{4} \rightarrow \mathrm{ZnSO}_{4}(\mathrm{~s})+4 \mathrm{HCN}(\text { gas })+\mathrm{SO}_{4}^{2-}
$$

The copper cyanide complex does not break down completely, even in strong acid solution, unless there is an oxidant present in the solution [12]. In the absence of oxidant, the copper tricyanide species (which is the most

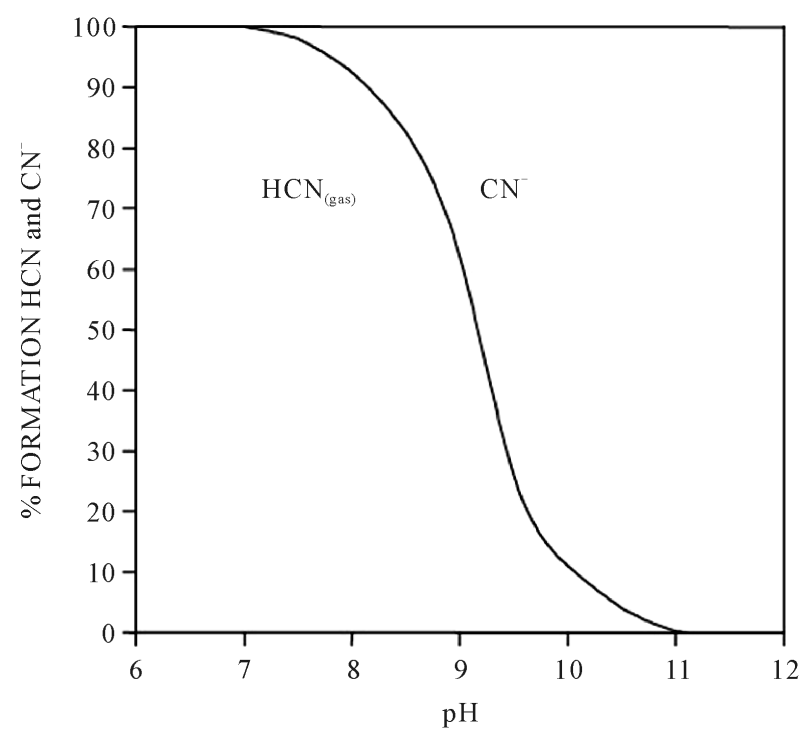

Figure 1. Equilibrium distribution diagram for free cyanide versus $\mathrm{pH}$. 
Table 1. Classification of cyanide and cyanide complexes on the basis of stability [11].

\begin{tabular}{cc}
\hline Classification & Compound \\
\hline $\begin{array}{c}\text { Free cyanide } \\
\text { Simple compounds } \\
\text { a) readily soluble } \\
\text { b) neutral insoluble salts } \\
\text { Weak complexes }\end{array}$ & $\mathrm{NaCN}, \mathrm{KCN}, \mathrm{Ca}(\mathrm{CN})_{2}, \mathrm{Hg}(\mathrm{CN})_{2}, \mathrm{Zn}(\mathrm{CN})_{2}$, \\
Moderately strong complexes & $\left.\mathrm{Cu}(\mathrm{CN})_{2}, \mathrm{CuCN}, \mathrm{Ni}(\mathrm{CN})_{2}, \mathrm{AgCN}\right)_{2}^{-1}, \mathrm{Cu}(\mathrm{CN})_{3}^{-2}, \mathrm{Ni}(\mathrm{CN})_{4}^{-2}, \mathrm{Ag}(\mathrm{CN})_{2}^{-1}$ \\
Strong complexes & $\mathrm{Fe}(\mathrm{CN})_{6}^{-4}, \mathrm{Co}(\mathrm{CN})_{6}^{-4}, \mathrm{Au}(\mathrm{CN})_{2}^{-1}, \mathrm{Fe}(\mathrm{CN})_{6}^{-3}$ \\
\hline
\end{tabular}

stable copper complex under normal cyanidation conditions: $\log B_{3}=28$ ) decomposes to form a CuCN precipitate, plus 2 moles of HCN gas in Equation (7), at pH values less than 3. Hence, $33 \%$ of potentially recoverable cyanide is lost to the precipitate:

$$
\mathrm{Cu}(\mathrm{CN})_{3}^{2-}+2 \mathrm{H}^{+} \rightarrow \mathrm{CuCN}(\mathrm{s})+2 \mathrm{HCN}_{(\text {gas })}
$$

Also, in our case, in the barren solution, the ferrocyanide and cuprous cyanide are present and at $\mathrm{pH}=4$, produce double metal cyanide precipitate such as $\mathrm{Cu}_{2} \mathrm{Fe}(\mathrm{CN})_{6}$ or $\mathrm{Cu}_{4} \mathrm{Fe}(\mathrm{CN})_{6}$ as in Equation (8):

$$
4 \mathrm{Cu}(\mathrm{CN})_{3}^{2-}+\mathrm{Fe}(\mathrm{CN})_{6}^{4-}+12 \mathrm{H}^{+} \rightarrow \mathrm{Cu}_{4} \mathrm{Fe}(\mathrm{CN})_{6}(\mathrm{~s})+12 \mathrm{HCN}_{(\mathrm{gas})}
$$

From the stoichiometry, it can be seen that the ferrocyanide molecule releases the third molecule of $\mathrm{CN}$ from the copper tricyanide complex, so the presence of ferrocyanide results in increased recovery of cyanide from the copper-cyanide species.

When thiocyanate is present, as is often the case when leaching sulphide-bearing ores, insoluble CuSCN may also be responsible for copper precipitation and in acid conditions, forming HCN gas; the following reaction (9) showed this behavior:

$$
\mathrm{Cu}(\mathrm{CN})_{3}^{2-}+\mathrm{SCN}^{-}+3 \mathrm{H}^{+} \rightarrow \mathrm{CuSCN}_{(\mathrm{s})}+3 \mathrm{HCN}_{(\mathrm{gas})}
$$

Also, the addition of sulphide ions $\left(\mathrm{Na}_{2} \mathrm{~S}\right)$ to the acidified cyanide solution results in the precipitation of cuprous sulphide (chalcocite), which is favored because of its extremely low solubility (Ksp $=2.3 \times 10^{-48}$ ) [7]. The following reaction takes place (Equation (10)):

$$
2 \mathrm{Cu}(\mathrm{CN})_{3}^{2-}+2 \mathrm{H}_{2} \mathrm{SO}_{4}+\mathrm{H}_{2} \mathrm{~S}_{\text {(gas) }} \rightarrow \mathrm{Cu}_{2} \mathrm{~S}_{(\mathrm{s})}+6 \mathrm{HCN}_{\text {(gas) }}+2 \mathrm{SO}_{4}^{2-}
$$

Stoichiometric usage of sulfide is approximately 0.25 grams $\mathrm{S}^{2-}$ per gram of copper, 0.44 grams NaHS per gram of copper or 0.61 grams $\mathrm{Na}_{2} \mathrm{~S}$ per gram of copper. However, the actual sulfide dosage required for nearcomplete copper precipitation is normal in excess of $200 \%$ due to additional ions in the barren solution. Also, in addition to precipitating copper and zinc, sulfide addition also results in the near-complete precipitation of silver sulfide, as shown in the following reaction (Equation (11)):

$$
2 \mathrm{Ag}(\mathrm{CN})_{2}^{-}+\mathrm{H}_{2} \mathrm{~S}_{\text {(gas) }} \rightarrow \mathrm{Ag}_{2} \mathrm{~S}_{\text {(s) }}+4 \mathrm{HCN}_{\text {(gas) }}
$$

As can be seen in reactions (Equation (6) to Equation (11)), when the formed $\mathrm{CN}^{-}$ions are converted to hydrocyanic acid and removed as hydrogen cyanide gas, the position of equilibrium will lie to the right in the reactions. As a result, significant increases will occur in dissociation in relation to several factors such as temperature, kinds of the samples, volatilization rate and time. Based upon the reactions [1], acid conditions may cause the dissociation of the complexes, due to the formation of some copper precipitate and subsequent liberation of HCN by volatilization. Also in accord with these reactions, up to $99 \%$ of copper could be recovered and HCN gas is stripping from the barren solutions and then adsorbed in an alkali solution of $\mathrm{NaOH}$. It has been almost 90 years since the Mills-Crowe process for cyanide regeneration was developed by the Compañía Beneficiadora de Pachuca México (England Patent No. 241669, 3.9.24) [10] and until today no significant changes to the process 
have been made [6]. The simplified chemistry of the process is presented in the following reactions (Equation (12) to Equation (14)):

$$
\begin{gathered}
\mathrm{CN}^{-}+\mathrm{H}^{+} \rightarrow \mathrm{HCN}_{(\text {aq) }} \quad \text { (acidification) } \\
\mathrm{HCN}_{\text {(aq) }} \rightarrow \mathrm{HCN}_{(\mathrm{g})} \quad \text { (volatilization) } \\
\mathrm{HCN}_{\text {(gas) }}+\mathrm{NaOH}_{(\text {aq) }} \rightarrow \mathrm{NaCN}_{(\text {aq) }}+\mathrm{H}_{2} \mathrm{O} \text { (recovery) }
\end{gathered}
$$

Then the precipitate is a saleable copper, zinc and silver product in its own right or can be blended with the bulk concentrate made from the tailings in the cyanidation process that has a residue of gold and silver.

\section{Materials and Methods}

The experiments were carried out on barren cyanide solution generated by the filter press on the Merrill-Crowe process. The pregnant solution came from the cyanidation leach plant (500 ton/day), where the ores is a mixture of oxides and sulfides, being the range of copper $0.04 \%$ to $0.25 \%$. The normal average samples contain $1.7 \mathrm{~g} /$ ton $\mathrm{Au}, 100 \mathrm{~g} / \mathrm{ton} \mathrm{Ag}, 0.6 \% \mathrm{~Pb}, 0.61 \% \mathrm{Zn}, 0.12 \% \mathrm{Cu}, 2.3 \% \mathrm{Fe}$ and $2 \%$ As. A wet screen analysis of the plant sample indicated that the granulometry was $80 \%-74 \mu \mathrm{m}(200 \mathrm{mesh})$. The leaching practice in the plant was: leach pulps containing $40 \%$ solids over a period of 72 hours leaching at $\mathrm{pH}=11.0, \mathrm{O}_{2}=5 \mathrm{ppm}$ and $2 \mathrm{~kg} /$ ton $\mathrm{NaCN}$; leached residue: $0.20 \mathrm{~g} / \mathrm{ton} \mathrm{Au}$ and $0.18 \mathrm{~g} / \mathrm{ton} \mathrm{Ag}$.

Copper precipitation and cyanide regeneration experiments were performed to determine the effect of different process conditions on the solids of copper/silver sulphide produced by sulphide precipitation. Precipitation experiments were carried out in a 1 liter round-bottomed reaction vessel with ports for an overhead stirrer, a gas sparger and a pH electrode. The pH meter is VWR 8005 Scientific and stirring motor with a glass impeller driven BDC 1850 CAFRAMO and cone size sedimentator $(1000 \mathrm{ml})$. The barren solutions used containing copper, silver, zinc and iron ions of varying concentration. The $\mathrm{pH}$ of the barren was adjusted to the required level with sulfuric acid and then mixture of $\mathrm{Na}_{2} \mathrm{~S} /$ water was added. In all precipitation experiments, samples of the liquor and solid were taken at different times and then, solutions and solids from the process were then separated by filtration through Whatman filter paper No. 42. The sludge from the precipitation was dried either in an oven or under vacuum at room temperature. Analysis of copper, silver, zinc, iron, and arsenic were performed by ICP/ Atomic Emission Spectrometry and free cyanide content was determined directly via titration, whereas the total cyanide was measured by means of titration after distillation. The recovering setup of cyanide in aqueous phase by regeneration consists of two parts made from glass. In the first part of the apparatus, acidification to form HCN and volatilization of formed HCN was performed. In the second part, HCN gas was absorbed in two columns of $\mathrm{NaOH}$ solution. At the end of the experiment, $\mathrm{HCN}$ volatilization reached efficiencies above $95 \%$ and the capture of cyanide gas by $\mathrm{NaOH}(1 \mathrm{M})$ solution was almost $95 \%$.

\section{Results and Discussion}

The experiments were carried out at different $\mathrm{pH}$ under atmospheric pressure in batch reactor in four-necked, one liter glass reaction cells, supported in a constant temperature bath in Figure 2. A condenser, stirrer, $\mathrm{H}_{2} \mathrm{~S}$ dispersion tube, and sampling device were placed into a reactor through the openings in the lid. The Teflon stirred was attached through the center port by means of a Chesapeake stirrer connection. The solution was stirred with a variable speed motor and the rotation speed was measured with a stroboscope. In all tests the initial barren solution from the Merrill-Crowe plant was from the same batch $(0.1 \mathrm{Ag}$ ppm, $184 \mathrm{Zn} \mathrm{ppm,} 636 \mathrm{Cu}$ ppm, $4 \mathrm{Fe} \mathrm{ppm}$ ). The following conditions were also fixed: temperature $25^{\circ} \mathrm{C}$, stirring speed $200 \mathrm{rpm}$, reaction time 90 seconds and addition of 0.5 to $2 \mathrm{~g} / \mathrm{l} \mathrm{Na} \mathrm{Na}_{2} \mathrm{~S}$. The experimental results of copper, silver, zinc and iron precipitation at different $\mathrm{pH}$ are presented in Table 2 and Table 3.

The results showed that $\mathrm{pH}$ had a great effect on copper cyanide removal efficiency and the optimum $\mathrm{pH}$ was about 3 to 4.0. At this $\mathrm{pH}$ value copper cyanide removal efficiency could be achieved above $99 \%$, when influent copper concentration ions were $636 \mathrm{ppm}$. Some black precipitates were observed in the solution samples of the pH 2 to 6 experiments; which suggested that there were copper, silver, arsenic, zinc and iron as sulphide.

Chemical composition by EDX is shown inside in Figure 3 and morphology of the solids in experiment $\mathrm{pH} 3$ are also shown by SEM in Figure 4. 


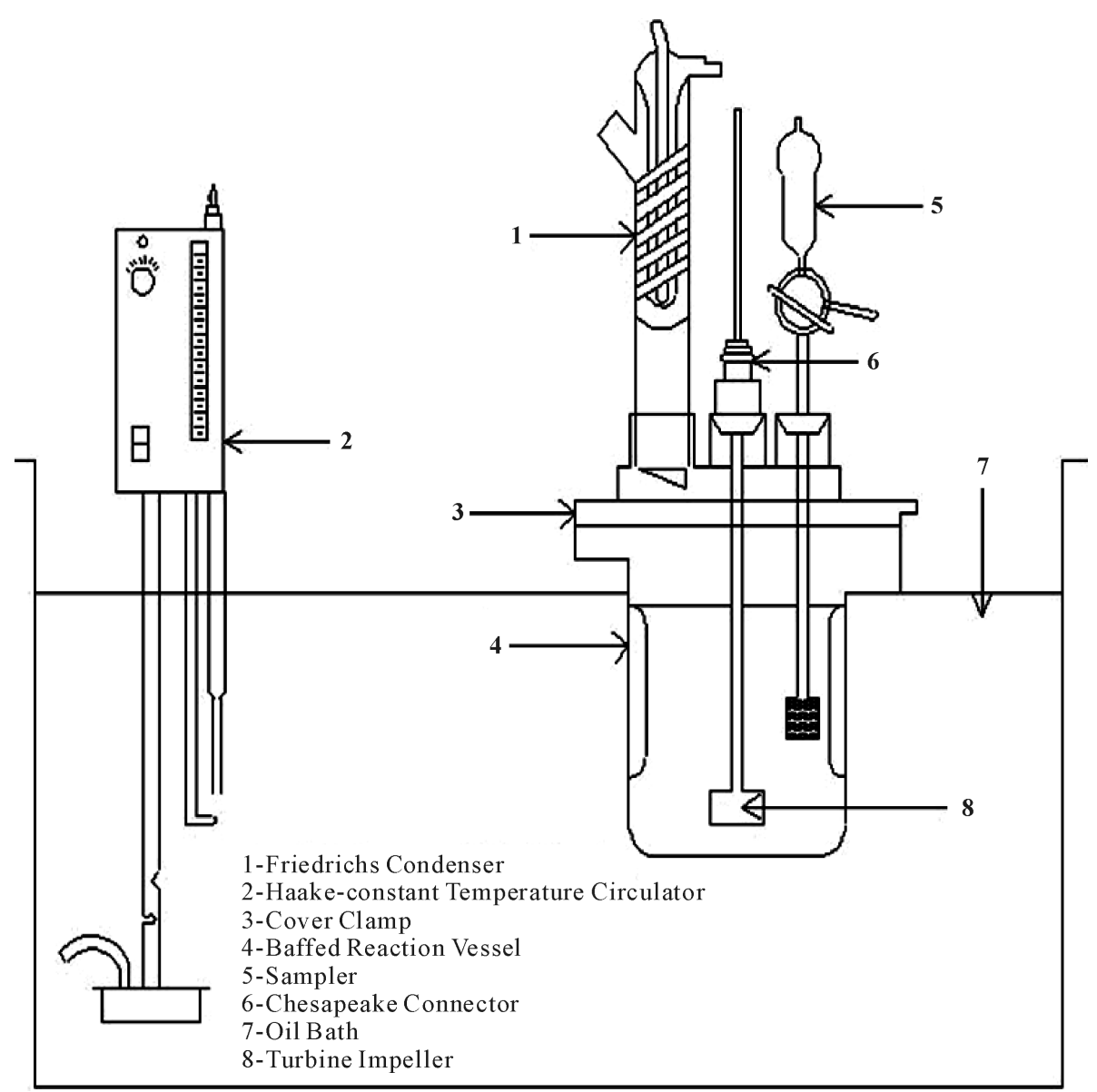

Figure 2. Schematic diagram of the experimental apparatus.

Table 2. Results of copper, silver, zinc and iron sulphide precipitates at different pHs (5.5 - 2.5) and concentrations of $\mathrm{Na}_{2} \mathrm{~S}$ $1 \mathrm{~kg} / \mathrm{m}^{3}$.

\begin{tabular}{|c|c|c|c|c|c|c|}
\hline & $\mathrm{Ag}$ & $\mathrm{Zn}$ & $\mathrm{Cu}$ & $\mathrm{Fe}$ & $\mathrm{Na}_{2} \mathrm{~S}(\mathrm{~g})$ & $\mathrm{pH}$ \\
\hline Feed barren solution (ppm) & 0.1 & 184 & 636 & 4 & 0 & 10.95 \\
\hline Solution 1 (ppm) & 0 & 22 & 31 & 2 & 1.0 & 5.5 \\
\hline Precipitate 1 (\%) & 114 & 11.90 & 51.70 & 1.0 & - & - \\
\hline Solution 2 (ppm) & 0 & 8 & 0 & 0 & 1.0 & 5.0 \\
\hline Precipitate 2 (\%) & 119 & 13.4 & 51.27 & 1.0 & - & - \\
\hline Solution 3 (ppm) & 0 & 32 & 0 & 0 & 1.0 & 4.5 \\
\hline Precipitate 3 (\%) & 138 & 9.92 & 56.34 & 0.9 & - & - \\
\hline Solution 4 (ppm) & 0 & 54 & 0 & 0 & $1 . .0$ & 4 \\
\hline Precipitate 4 (\%) & 118 & 1.49 & 62.68 & 1.1 & - & - \\
\hline Solution 5 (ppm) & 0 & 40 & 0 & 0 & 1.0 & 3.0 \\
\hline Precipitate 5 (\%) & 129 & 9.53 & 62.24 & 1.1 & - & - \\
\hline Solution 6 (ppm) & 0 & 134 & 0 & 0 & 1.0 & 2.5 \\
\hline Precipitate 6 (\%) & 106 & 11.24 & 60.5 & 0.9 & - & - \\
\hline
\end{tabular}


Table 3. Chemical composition determined by EDX for different $\mathrm{pH}$ values.

\begin{tabular}{|c|c|c|c|c|c|c|}
\hline \multirow{2}{*}{ Element } & \multicolumn{2}{|c|}{$\mathrm{pH}=2$} & \multicolumn{2}{|c|}{$\mathrm{pH}=3$} & \multicolumn{2}{|c|}{$\mathrm{pH}=4$} \\
\hline & Weight \% & Atomic \% & Weight \% & Atomic \% & Weight \% & Atomic \% \\
\hline $\mathrm{O} \mathrm{K}$ & 7.69 & 20.37 & 9.64 & 24.35 & 7.73 & 20.03 \\
\hline Na K & 2.30 & 2.40 & 2.6 & 2.7 & 2.51 & 4.52 \\
\hline S K & 27.85 & 33.71 & 29.02 & 33.86 & 26.44 & 34.18 \\
\hline Ca K & 0.5 & 0.70 & 0.60 & 0.61 & 0.45 & 0.46 \\
\hline $\mathrm{Fe} \mathrm{K}$ & 2.06 & 1.56 & 1.96 & 1.42 & 1.90 & 1.41 \\
\hline $\mathrm{Cu} \mathrm{K}$ & 43.46 & 28.98 & 41.19 & 26.19 & 39.94 & 26.06 \\
\hline Zn K & 16.14 & 12.28 & 17.58 & 10.87 & 21.04 & 13.34 \\
\hline Totals & 100.00 & 100 & 100.00 & 100 & 100.00 & 100 \\
\hline
\end{tabular}

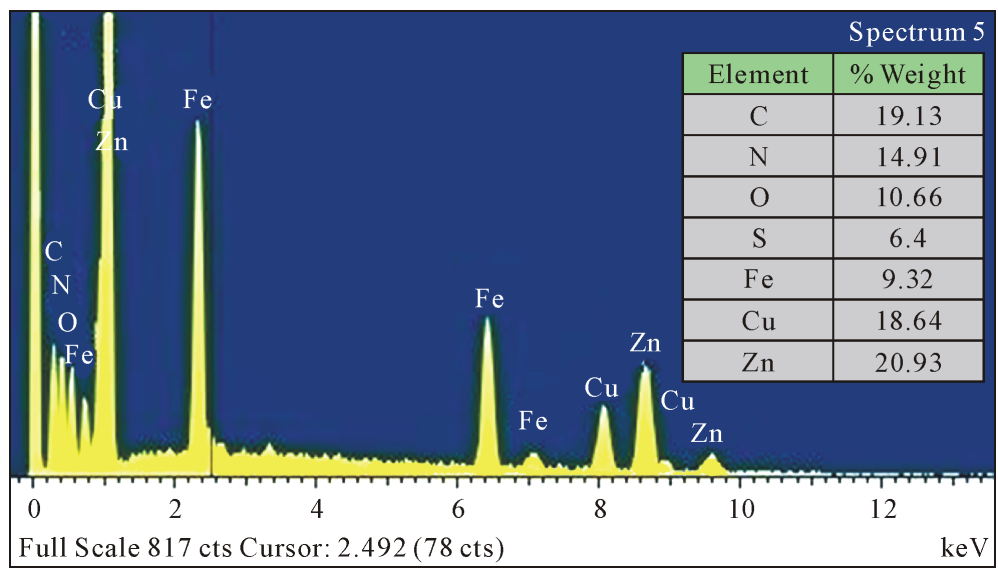

Figure 3. Chemical composition by EDX of the solid in experiment $\mathrm{pH}=3.0$.

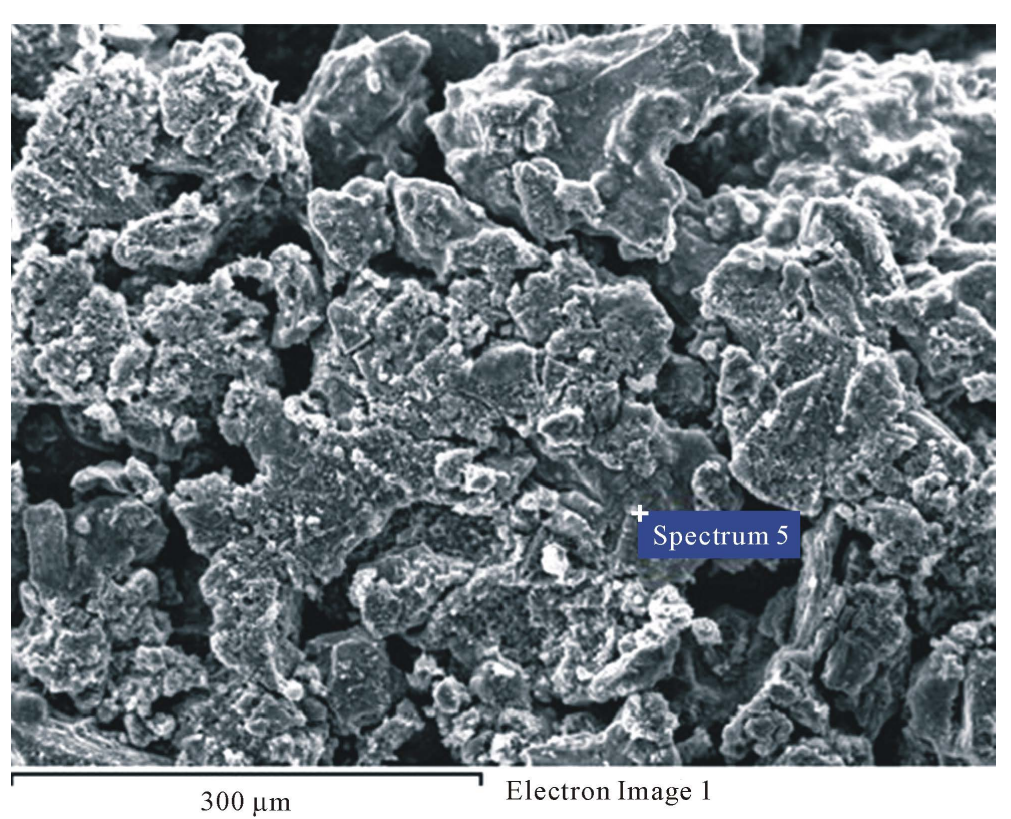

Figure 4. Morphology of the solids in experiment $\mathrm{pH}=3$ shown by SEM. 
Also in Figure 3, shows the presence of copper, sulphur, zinc and iron in the sulphide precipitate particle.

The SEM in Figure 4 confirms the excellent crystallinity of synthetic covellite (CuS) formed during sulphide precipitation process. The solids in the precipitate are of different shapes and approximately $100 \mathrm{~nm}$ in diameter.

The results in Table 3, indicated that the $\mathrm{pH}=3$ value is the best condition for sulphide precipitation of copper.

\subsection{Industrial Application}

In base on the experimental evidence obtained with the sulphide precipitation study for copper and cyanide removal from the barren solution after the Merrill-Crowe process. This process has been installed on a mine site at full scale. A simplified process flow diagram, using sodium sulphide to precipitate copper and silver, and convert cyanide to HCN gas, under acidic conditions (pH 3 to 4) is shown in Figure 5.

The serpentine system is a viable technology for the recovery of copper, silver and subsequent recovery of HCN gas by scrubbing in $\mathrm{NaOH}$. Barren solution is currently fed to the serpentine at 10 to 15 liters/s at a pH 11 . At this flow rate, the precipitate of calcium sulphate (scale) would not occur. In five continuous working days the treated solution exits the circuit at a $\mathrm{pH}$ of 3, carrying about 0 to $10 \mathrm{ppm}$ of copper and $200 \mathrm{ppm}$ cyanide and is pumped to two neutralizing ( $\mathrm{pH} 7$ ) tanks. The operation of the serpentine produce high grade copper sulphide precipitate in the range of $40 \%$ to $55 \%$ of Cu with $130 \mathrm{gr} / \mathrm{ton} \mathrm{Ag}$ and recoveries of cyanide of $90 \%$.

\subsection{Removal of Lead Hydroxides Complexes in Pregnant Solution Rich in Gold and Silver Cyanide Ions, by Using Hydroxyapatite Natural Powder}

There are several methods for lead ions removal from industrial wastewater: chemical precipitation (hydroxide precipitation, sulfide precipitation, carbonate precipitation, and so on); physical treatment (ion exchange, adsorption and foam flotation). In particular, treatment of processes for lead removal from waste water must be

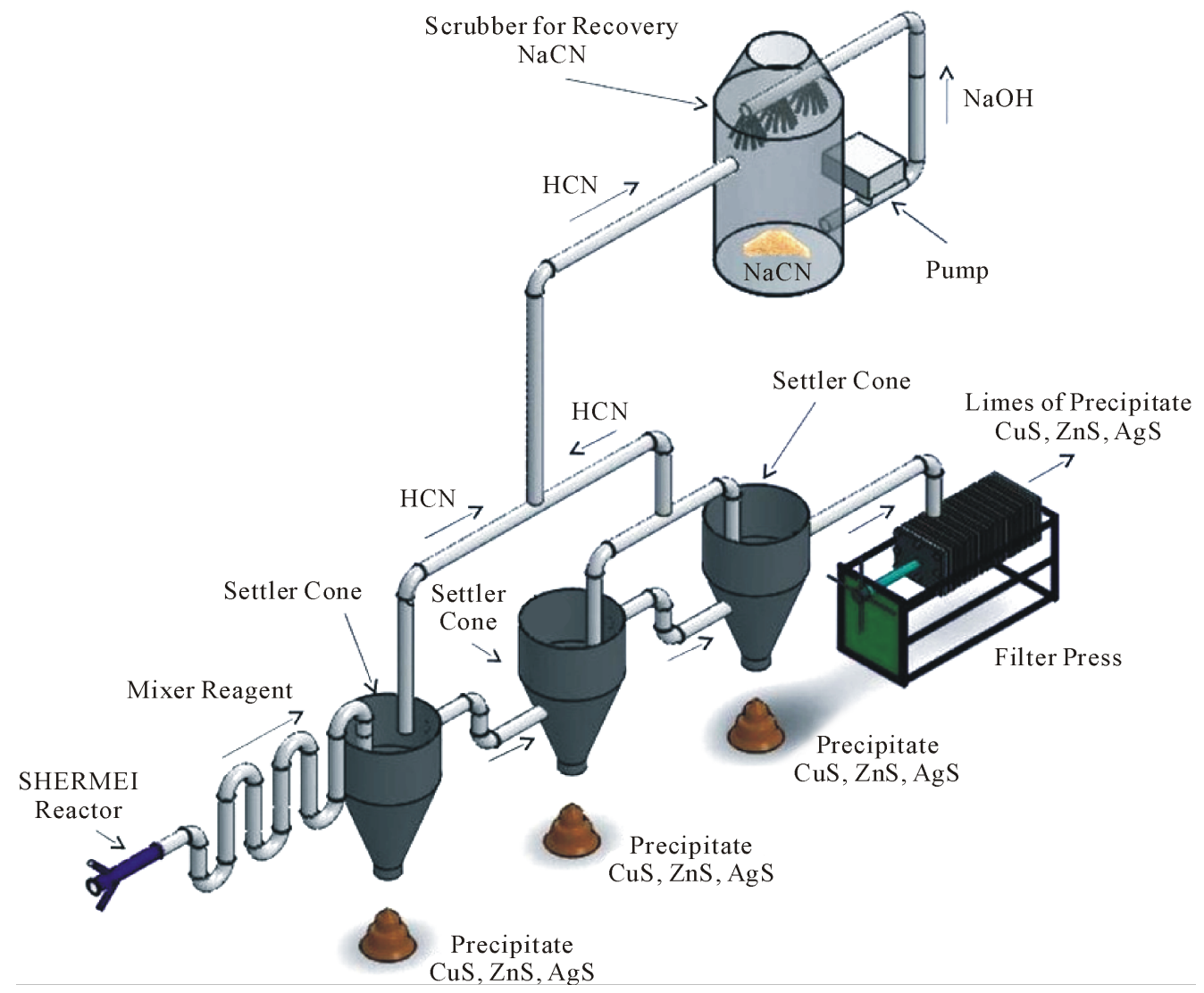

Figure 5. A schematic diagram of the serpentine industrial plant. 
selected to remove the existing form of lead ions [13] [14]. In general, lead is precipitated or otherwise attached to an insoluble form through adsorption or ion exchange. Treatment processes for lead removal from water and waste water through adsorption or ion exchange were recently studied.

Increasingly stringent regulations have created a growing interest in the development of novel processes for removal of lead oxides and hydroxides from the pregnant cyanide solution, before the cementation in the filter press. One feasible option is a treatment processes for removal of lead hydroxides from cyanide liquors through adsorption on animal powder bone (hydroxyapatite $\left.\mathrm{Ca}_{10}\left(\mathrm{PO}_{4}\right)_{6}(\mathrm{OH})_{2}\right)$, which is an economical and natural source of phosphate that has a high removal capacity for divalent heavy metal ions. In the present research, we performed a new approach for cleaning the precious precipitate of plumbite ions. Natural bone contain high amount of $\mathrm{Ca}$ and $\mathrm{P}$ in the form of hydroxyapatite and thus represent a potential resource with possible application in the remediation contamination of lead in the precious precipitate of gold and silver.

Natural bone has the potential for application in the treatment of the pregnant liquor of the cyanidation contaminated with lead ions. It was used as adsorbent. The bones were supplied by a company involved in commercial meat by products, It was chopped into small pieces, washing with lime $\left(\mathrm{Ca}(\mathrm{OH})_{2}\right)$ and dried in sunlight until the moisture was partially evaporated, and further dried in the hot air oven at $60^{\circ} \mathrm{C}$ for $24 \mathrm{~h}$. It was then sieved and particles ranging from 125 to $180 \mu \mathrm{m}$ were used for the study. The sieved powder bones were then used in the sorption experiments as described in the following sections. Physical and chemical characteristics of the bones are summarized in Table 4.

\subsection{Batch Adsorption Experiments}

A stock solution of $20 \mathrm{mg} / \mathrm{dm}^{3}$ lead (II) was prepared with the pregnant liquor of the cyanidation plant. Was studied by shaking the solution (model L orbital) at $300 \mathrm{rpm}$, using $1000 \mathrm{~cm}^{3}$ of $20 \mathrm{mg} \cdot \mathrm{dm}^{-3}$ solution of $\mathrm{Pb}$ (II) containing $100 \mathrm{mg}$ of the adsorbent bone and adjusted to an initial $\mathrm{pH}$ of 11.0 at constant temperature of $25^{\circ} \mathrm{C}$. After agitation for 30 minutes, the adsorbate was separated using a $0.45 \mu \mathrm{m}$ cellulose acetate filter. The solution samples were analyzed for $\mathrm{Pb}, \mathrm{Ag}$ and $\mathrm{Au}$. The quality control of the solution analysis was achieved by using appropriate blank control.

The effect contact time on uptake of lead adsorbed from cyanide liquors by the use of different amounts of bone powder in Figure 6. It is apparent that the uptake of lead ions by the bone increased by increasing the amount of bone powder and the time affect of adsorption of lead on the bone powder reaches equilibrium state after 30 minutes.

\subsection{Characterization of Clean Bone and Bone with 20 ppm Pb, High Resolution X-Ray Micro Tomography (HRXMT) Scans}

Two bone samples, namely clean (50 - 70) and bone with $20 \mathrm{ppm}$ Pb, were scanned using the HRXMT facility. operation parameters for the HRXMT scans are summarized as follow: $60 \mathrm{KV}, 4 \times$ lens, 10 second exposure time, $150 \mu \mathrm{m}$ glass filter, 1000 projected views, $360^{\circ}$ rotation, and 5.04 micron reconstructed resolution.

In Figure 7 presents the 2D slice and the zoom image for bone sample with $20 \mathrm{ppm} \mathrm{Pb}$. The lead is clearly on the surface regions of the bone particles. The 3D image consists of $992 \times 1013 \times 992$. The size of each voxel is $5.04 \times 5.04 \times 5.04 \mu \mathrm{m}$.

This image show that the bone samples by micro CT not much internal surface area is found at this CT resolution as might be expected from the low BET surface area.

\begin{tabular}{cc|}
\hline Table 4. Physical and chemical characteristics of bone. \\
\hline Parameter & Value \\
\hline Moisture $(\%)$ & Nil \\
Surface area $\left(\mathrm{m}^{2} \cdot \mathrm{g}^{-1}\right)$ & 0.344 \\
Particle size $(\mu \mathrm{m})$ & $147-417$ \\
Water-soluble matter $(\%)$ & Nil \\
Apparent density $\left(\mathrm{g} \cdot \mathrm{cm}^{-3}\right)$ & 0.20 \\
\hline
\end{tabular}




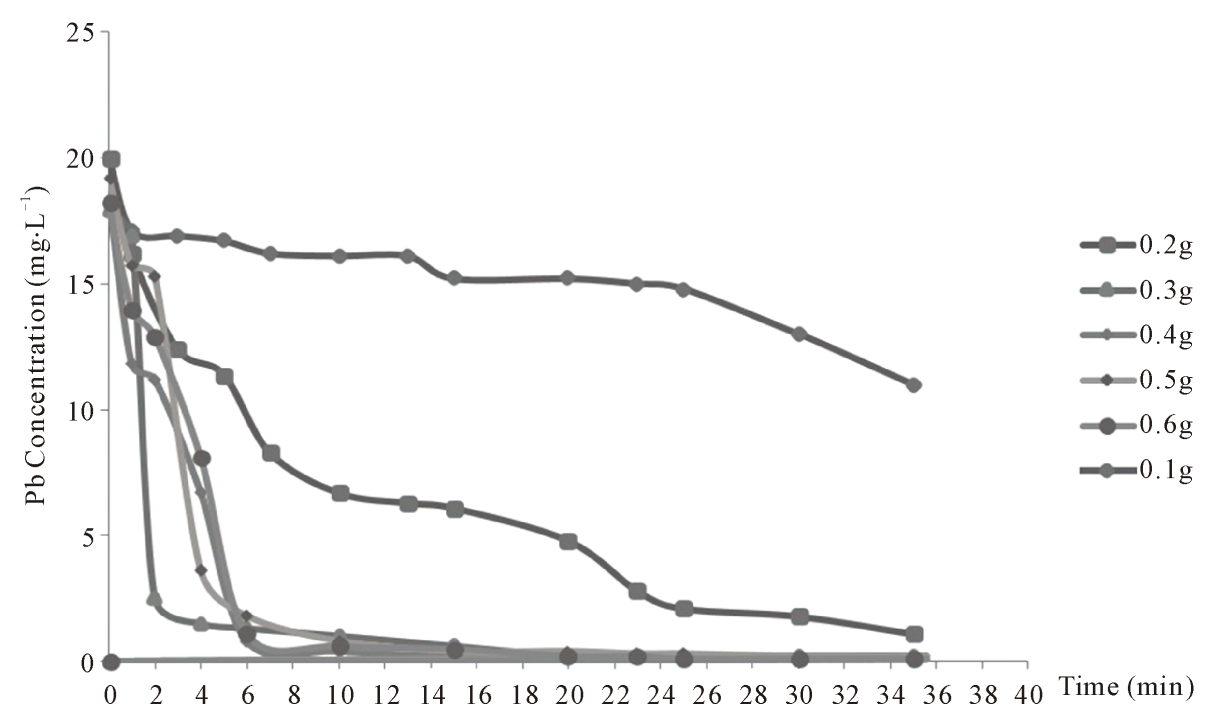

Figure 6. Effect of contact time on uptake of lead adsorbed from cyanide liquors by the use of different amounts of bone powder.

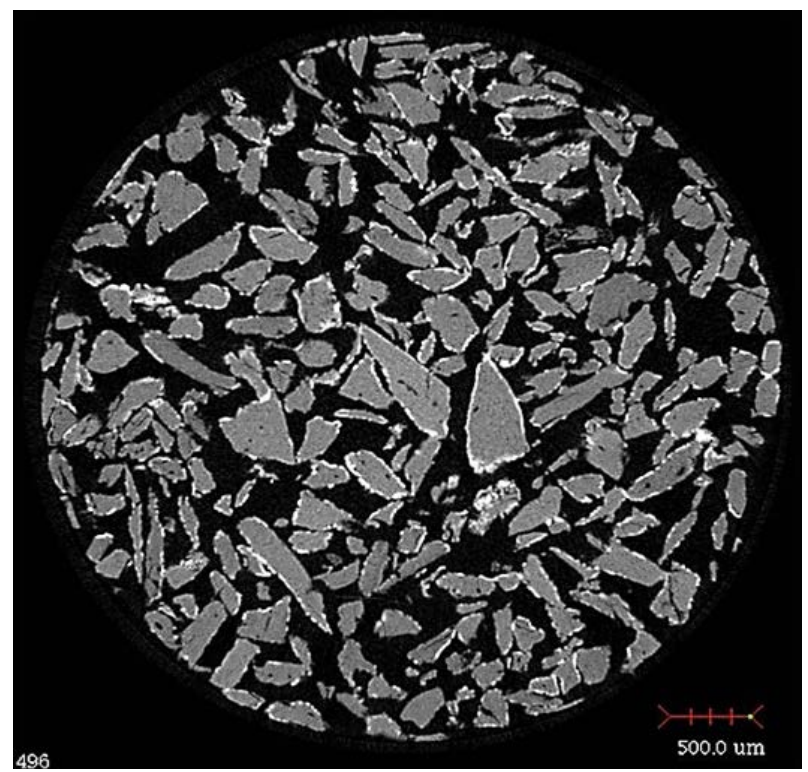

Figure 7. 2D sliced image of bone sample with $20 \mathrm{ppm} \mathrm{Pb.}$

\subsection{X-Ray Characterization}

The bovine bone powder metal-free was analyzed by X-ray diffractometer, Bruker-AXS, model D8 Discover GADDS. Each sample was exposed to radiation $\mathrm{CuK} \alpha_{1}$ for 60 seconds. The pattern was recorded in the range of $6^{\circ}-70^{\circ} 2 \theta$. The X-ray diffractogram of bovine bone particles of 254.5 microns in diameter is shown in Figure 8.

From Figure 8, the characteristic major peaks $\mathrm{X}$-ray pattern reported in the literature for hydroxyapatite are clearly observed, these are at $2 \theta=32^{\circ}, 32.5^{\circ}$ and $33^{\circ}$, accompanied by some secondary less intense peaks located at $2 \theta=26^{\circ}, 46.5^{\circ}$ and $49^{\circ}$, likewise there are some other even less intense at $2 \theta=34^{\circ}$ and $39.5^{\circ}$.

All those diffraction pattern peaks are visible in Figure 8. Also, they are matched with the standard data base values for hydroxyapatite. This confirmed the presence of hydroxyapatite in the bone powder in Figure 9 shows an overlay of XRD pattern of sample of CBP mixed with lead solution (50 ppm).

According to Figure 9, these XRD pattern match with the standard hydroxylpyromorphite $\left(\mathrm{Pb}_{5}\left(\mathrm{PO}_{4}\right)_{3} \mathrm{OH}\right)$ pattern of the PDF-Maint data base. 


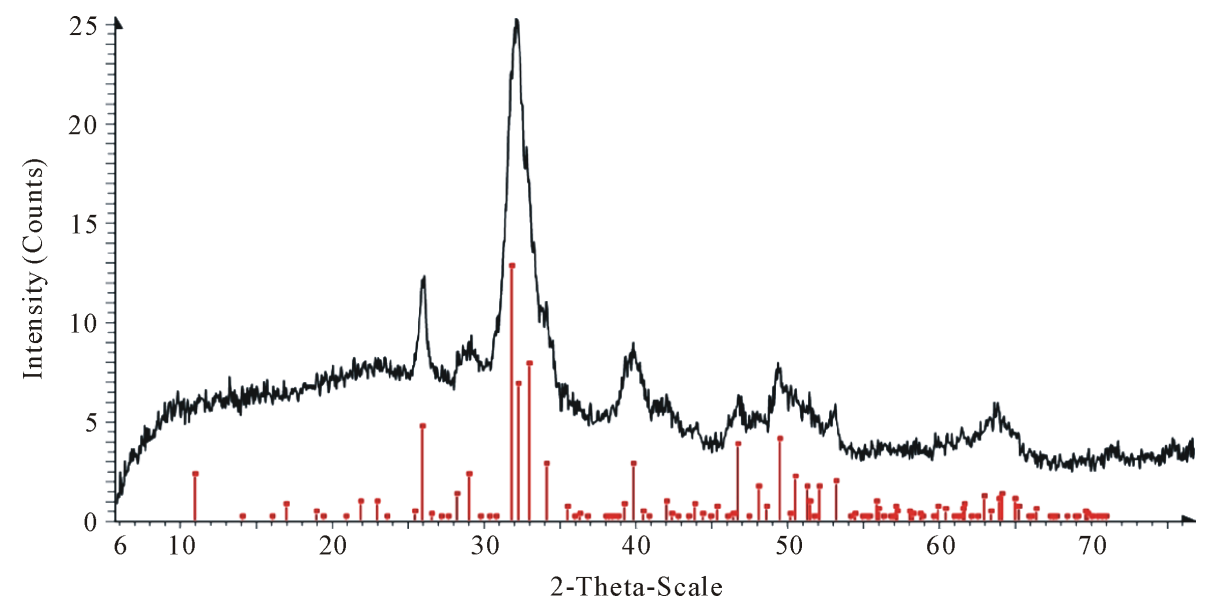

Figure 8. XRD patterns of initial CBP with a size of $254.5 \mu \mathrm{m}$. Line diffraction pattern indicates synthetic hydroxyapatite, and the black pattern indicate CBP.

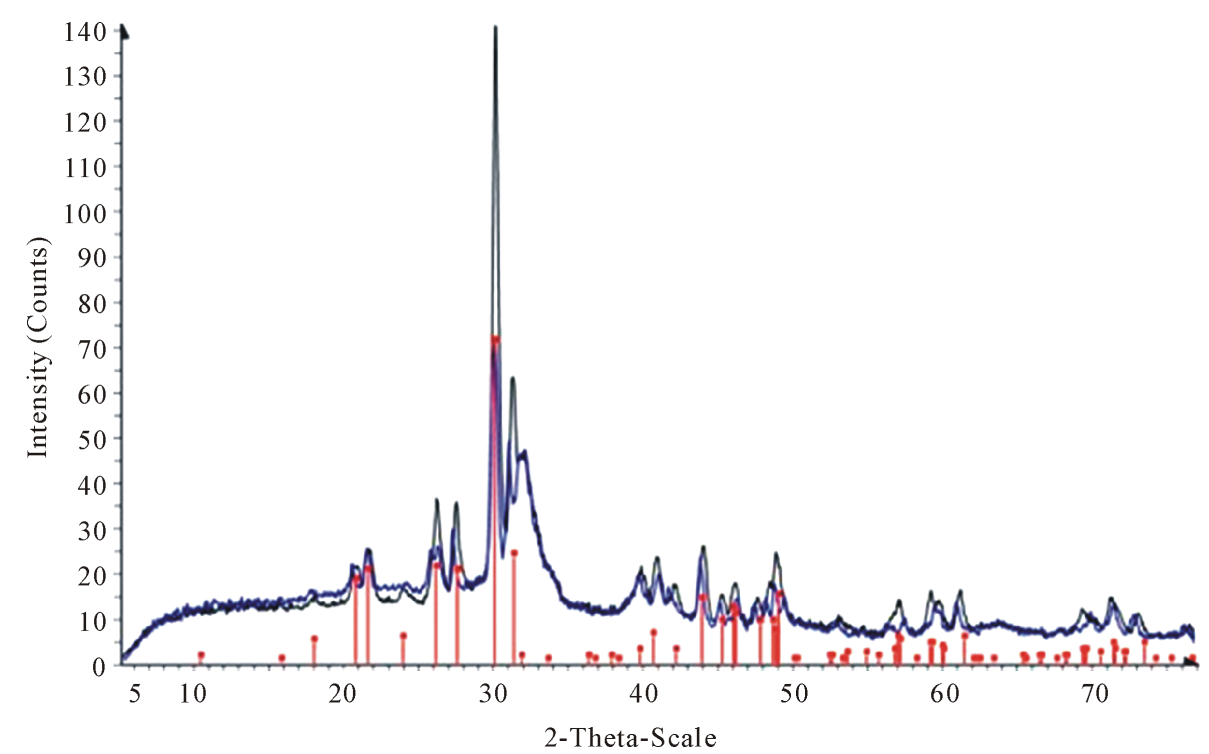

Figure 9. XRD pattern of CBP after contact with concentrations of lead solutions. Darker diffraction pattern indicate XRD for $50 \mathrm{ppm}$ and the line pattern is hydroxypyromorphite.

This new phase is a product after interaction of $\mathrm{CBP}$ with $\mathrm{Pb}^{+2}$ solutions, and a different phase than that of the CBP itself. This confirms the adsorption of lead on the bone powder. By comparing Figure 8 and Figure 9, it can be concluded that lead adsorption occurs on the external particle surfaces. The newly found phase (hydroxylpyromorphite) suggests that the mechanism of adsorption is not directly by ion exchange.

\subsection{Industrial Application}

In base on the experimental evidence obtained with the hydroxyapatite particles bonds study for lead removal from the pregnant solution before the Merrill-Crowe process, in BACIS mining recovery plant. This process has been installed on a mine site at full scale, as shown in Figure 10. The industrial results showed that the removal of lead, from the pregnant solution, was $99 \%$ and the quality of the precipitate was improved three times respect previous results.

Also, the serpentine process has been used in BACIS Mining Company in México, to treat cyanide-bearing effluents. In Table 5, are shown initial and final concentrations of cyanide, zinc and copper cyanide complex, for the serpentine process. 

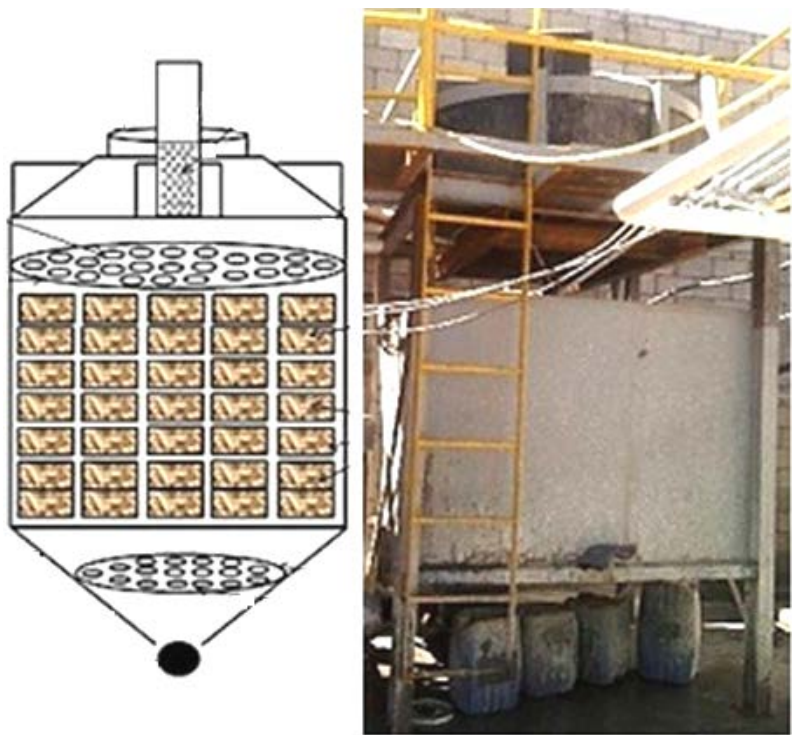

Figure 10. The process of the filter with natural hydroxyapatite particles.

Table 5. Characteristic of the cyanide-bearing effluents from BACIS mine.

\begin{tabular}{ccc}
\hline & {$[\mathrm{C}]_{\text {initial }}(\mathrm{ppm})$} & {$[\mathrm{C}]_{\text {final }}(\mathrm{ppm})$} \\
\hline $\mathrm{CN}$ free & 1000 & $<0.02$ \\
$\mathrm{CN}$ total & 13,000 & $<0.02$ \\
$\mathrm{Zn}$ & 8500 & $<20$ \\
$\mathrm{Cu}$ & 8000 & $<100$ \\
$\mathrm{~Pb}$ & 120 & $<1$ \\
\hline
\end{tabular}

In this mining, the percentage removal varies from 95 percent to over 99 percent for total and free cyanide and the cyanides ions of copper, lead and zinc are removed $99 \%$.

\section{Conclusions}

The advantages of the serpentine plant include high precipitation rate of copper, zinc and silver (99\%), compact treatment facility, relatively low operation cost, and a saleable copper/silver product. The main advantages of using the serpentine are: the low energy that is used and finally, production of high grade copper sulphide precipitate in the range from $40 \%$ to $55 \%$ of $\mathrm{Cu}$ with $130 \mathrm{gr} \cdot \mathrm{ton}^{-1} \mathrm{Ag}$ and recoveries of cyanide of $90 \%$.

Also, from this study we can conclude that bone powder is an excellent adsorbent for lead hydroxides ions. The results showed that the elimination of lead ions, from the pregnant rich solution from BACIS mine, with natural hydroxyapatite (from bones) was 99\%. Finally, the precipitate in both companies, BACIS and WILLIAM improve the quality 4 times regarding the previous results.

\section{Acknowledgements}

The authors wish to acknowledge support of this project to WILLIAM Mining and BACIS Group in Mexico the National Council of Science and Technology (CONACYT) and TNM Institute Technology of Saltillo, Mexico.

\section{References}

[1] Lewis, A.E. (2010) Review of Metal Sulphide Precipitation. Hydrometallurgy, 104, 222-234. 
http://dx.doi.org/10.1016/j.hydromet.2010.06.010

[2] Habashi, F. (1987) One Hundred Years of Cyanidation Historical Note. CIM Bulletin, 30, 108-114.

[3] Parga, J.R., Valenzuela, J.L. and Cepeda, F. (2007) Pressure Cyanide Leaching for Precious Metals Recovery. Journal of Metals, 59, 43-47.

[4] Hedjazi, F. and Monhemius, J. (2014) 64 Copper-Gold Ore Processing with Ion Exchange and SART Technology. Minerals Engineering, 64, 120-125. http://dx.doi.org/10.1016/j.mineng.2014.05.025

[5] Dai, X. and Jeffrey, M.I. (2006) The Effect of Sulfide Minerals on the Leaching of Gold in Aeratedcyanide Solutions. Hydrometallurgy, 82, 118-125. http://dx.doi.org/10.1016/j.hydromet.2006.03.005

[6] Parga, J.R., Casillas, H.M., Vazquez, V. and Valenzuela, J.L. (2009) Cyanide Detoxification of Mining Wastewaters with $\mathrm{TiO}_{2}$ Nanoparticles and Its Recovery by Electrocoagulation. Chemical Engineering and Technology, 32, 19011908. http://dx.doi.org/10.1002/ceat.200900177

[7] Adams, M., Lawrence, R. and Bratty, M. (2008) Biogenic Sulphide for Cyanide Recycle and Copper Recovery in Gold-Copper Ore Processing. Minerals Engineering, 21, 509-517. http://dx.doi.org/10.1016/j.mineng.2008.02.001

[8] Dybowska, A. and Woodgate, S. (2009) An Evaluation of the Reactivity of Synthetic and Natural Apatites in the Presence of Aqueous Metals. Science Total Environmental, 407, 2953-2965. http://dx.doi.org/10.1016/j.scitotenv.2008.12.053

[9] Mping, C.N., Bradshaw, S.M., Akdogan, G., Snyders, C.A. and Eksteen, J.J. (2013) Evaluation of the Merril-Crowe process for the Simultaneous Removal of Platinum, Palladium and Gold from Cyanide Leach Solutions. Hydrometallurgy, 142, 36-46. http://dx.doi.org/10.1016/j.hydromet.2013.11.004

[10] Lawr, C.W. (1929) Cyanide Regeneration as Practiced by Compañia Beneficiadora de Pachuca. England Patent No. 241669.

[11] Smith, A. and Mudder, T. (1991) The Chemistry and Treatment of Cyanidation Wastes. Mining Journal Books Limited, London.

[12] Muir, D.M. (2011) A Review of the Selective Leaching of Gold from Oxidised Copper-Gold Ores with Ammonia-Cyanide and New Insights for Plant Control and Operation. Minerals Engineering, 24, 576-582. http://dx.doi.org/10.1016/j.mineng.2010.08.022

[13] Kong, J.J., Yue, Q., Sun, S., Gao, B., Kan, Y., Li, Q. and Wang, Y. (2013) Adsorption of Pb(II) from Aqueous Solution Using Keratin Waste-Hide Waste: Equilibrium, Kinetic and Thermodynamic Modeling Studies. Chemical Engineering Journal, 241, 393-400. http://dx.doi.org/10.1016/j.cej.2013.10.070

[14] Yan, Y., Dong, X., Sun, X., Sun, X., Li, J., Shen, J., Han, W., Liu, X. and Wang, L. (2014) Conversion of Waste FGD Gypsum into Hydroxyapatite for Removal of $\mathrm{Pb}^{2+}$ and $\mathrm{Cd}^{2+}$ from Wastewater. Journal of Colloid Interface Science, 429, 68-76. http://dx.doi.org/10.1016/j.jcis.2014.05.010 
Scientific Research Publishing (SCIRP) is one of the largest Open Access journal publishers. It is currently publishing more than 200 open access, online, peer-reviewed journals covering a wide range of academic disciplines. SCIRP serves the worldwide academic communities and contributes to the progress and application of science with its publication.

Other selected journals from SCIRP are listed as below. Submit your manuscript to us via either submit@scirp.org or Online Submission Portal.
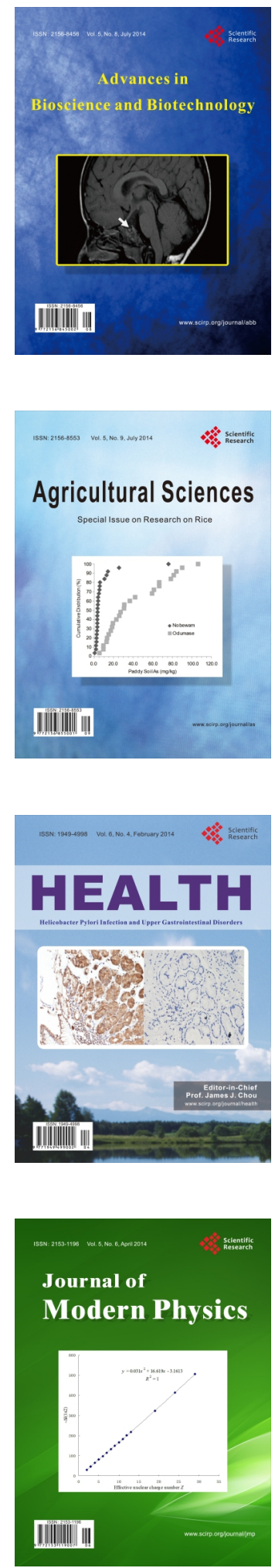
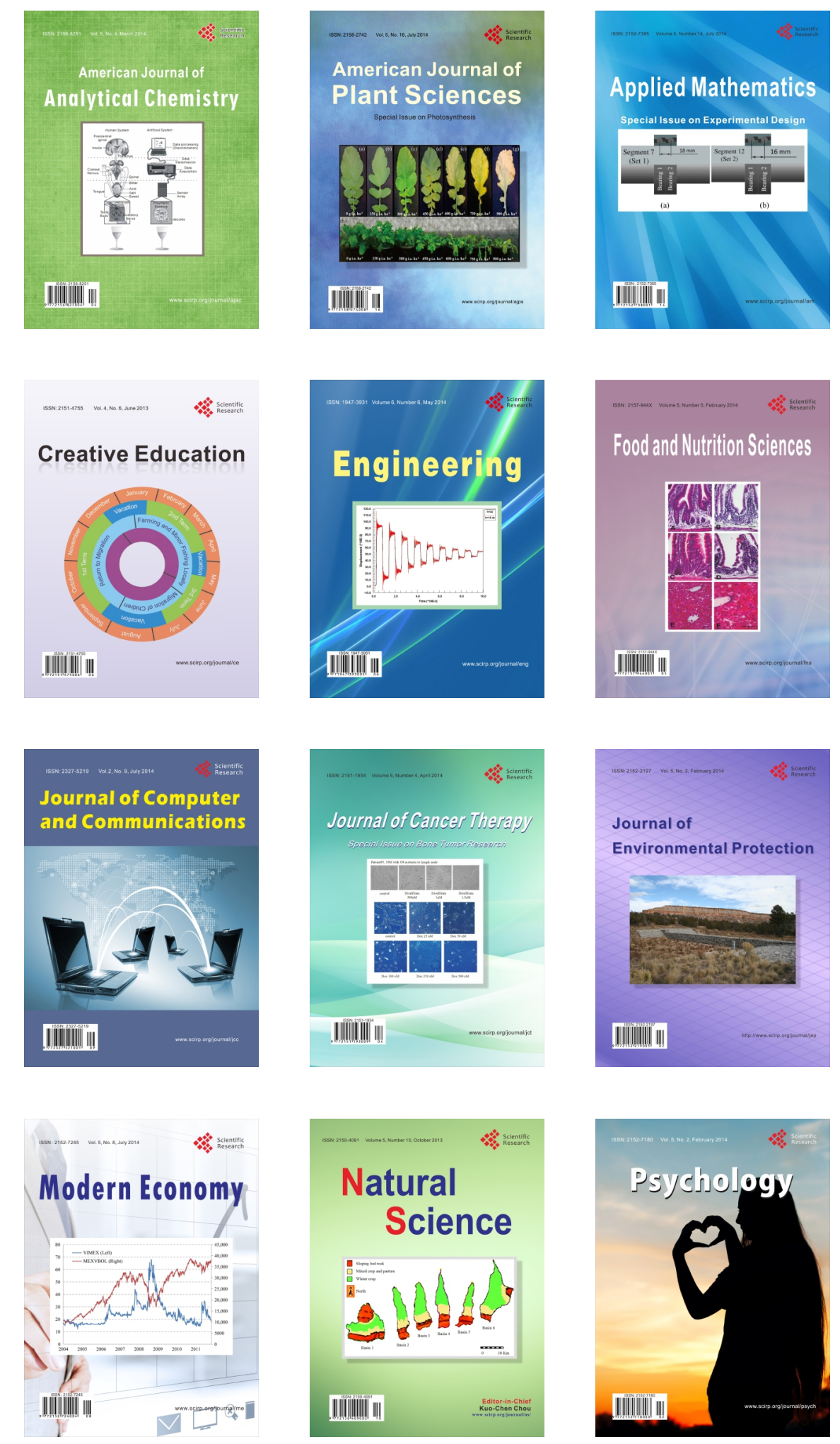